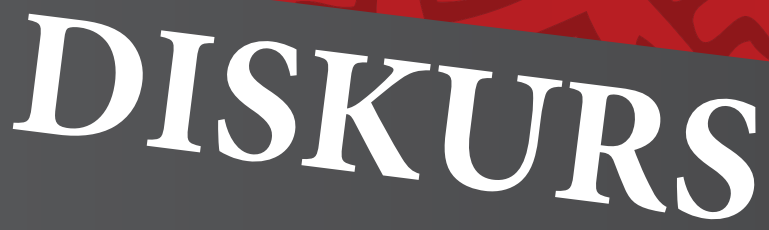

I POLITIKA

\title{
DISCOURSE AND POLITICS
}

\author{
Priredili/Edited by \\ Dejana Vukasović \\ Petar Matić
}

International Thematic Collection of Papers

Book 8

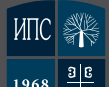

$1968 \frac{\frac{\partial]}{316}}{316}$

2019 


\title{
DISKURS I POLITIKA
}

\section{DISCOURSE AND POLITICS}

\author{
PRIREDILI/EDITED BY \\ Dejana M. Vukasović \\ Petar Matić
}

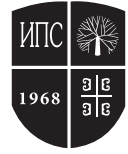




\title{
DISCOURSE AND POLITICS
}

International Thematic Collection of Papers

\author{
Publisher \\ Institute for Political Studies, Belgrade \\ https://doi.org/10.22182/dispol \\ Dr Živojin Đurić
}

Editors

Dr Dejana M. Vukasović

Dr Petar Matić

\section{Reviewers}

Prof dr Jean-Denis Mouton, Université de Lorraine/Université Paris 2, Panthéon-Assas, Paris

Prof dr Krzysztof Jaskulowski, SWPS University, Warsaw

Prof dr Siniša Atlagić, Fakultet političkih nauka, Beograd

Prof dr Jelena Đorđević, Fakultet političkih nauka, Beograd

\section{Editorial board}

Dr Živojin Đurić, Institut za političke studije, Beograd

Prof dr Lino Veljak, Department of Philosophy, Faculty of Humanities, University of Zagreb

Prof dr Dobrivoje Stanojević, Fakultet političkih nauka, Beograd

Prof dr Raluca-Mihaela Levonian, University of Udine

Prof dr Marija Đorić, Institut za političke studije, Beograd

Prof dr Ivana Damjanović, Fakultet političkih nauka, Beograd

Prof dr Maja Kovačević, Fakultet političkih nauka, Beograd

Dr Piotr Majewski, SWPS University, Warsaw, Poland

Dr Ekatharina Khovanova, Belgorod State University, Belgorod,

Dr Andrei Polonsky, Belgorod State University, Belgorod,

Dr Dušan Dostanić, Institut za političke studije, Beograd

Dr Aleksandar Novaković, Institut za političke studije, Beograd

\section{Technical Assistants}

Bojana Sekulić, Institut za političke studije, Beograd Andrijana Jovanović, Institut za političke studije, Beograd

Administrative Secretary

Smiljana Paunović

\section{Copies}

100

Printed by

Sitoprint, Žitište 


\section{TABLE OF CONTENTS}

I POLITICAL PHILOSOPHY AND

UNDERSTANDING OF DISCOURSE

Alpar Lošonc

DISCURSIVE DEPENDENCE OF POLITICS

WITH THE CONFRONTATION BETWEEN

REPUBLICANISM AND NEOLIBERALISM

23-46

Lino Veljak

PHILOSOPHY BETWEEN DISCOURSE OF RELIGION AND DISCOURSE OF SCIENCE

Bogdana Koljević Griffith

POLITICS, PHILOSOPHY, DEMOCRACY:

FOUCAULT AND RANCIERE

63-80

Vesna Stanković Pejnović

THE POWER OF DISCOURSE FROM

FOUCAULT'S PERSPECTIVE

Valerio Fabbrizi

POLITICAL DISCOURSE AND REASONABLE DISAGREEMENT - WHAT CONSTITUTIONALISM SUGGESTS 
Ivan Matić

THE RIGHT TO BE WRONG: THEORETICAL AND PRACTICAL ASPECTS OF FREEDOM OF SPEECH IN PUBLIC DISCOURSE

\section{CASE STUDIES AND DISCOURSE IN CONTEMPORARY POLITICAL PROCESSES}

Ruth Breeze

APPROACHING POPULIST DISCOURSE FROM LINGUISTICS: GRADUATION IN POLITICAL SPEECHES

Raluca Levonian

SELF-LEGITIMATING STRATEGIES IN THE DISCOURSE OF POLITICAL LEADERS: A COMPARATIVE ANALYSIS OF TWO ROMANIAN POLITICIANS

Evgeny A. Kozhemyakin, Svetlana V. Kryukova CONSTRUCTION OF NATIONAL IDENTITY IN POLITICAL DISCOURSE: CASES OF PRESIDENTIAL NEW YEAR TV ADDRESSES AND APPEALS TO THE FEDERAL ASSEMBLY

Juraj Marušiak

CHANGE OF POLITICAL LANDSCAPE IN CENTRAL EUROPE SINCE 2010 
Dobrivoje Stanojević, Lidija Mirkov

POPULISTIC STYLE AND LEADERS'

PATHETICS 255-268

Sanja Lazarević Radak

A DISCOURSE ON THE EUROPEAN PATH OF SERBIA CRISIS OR CHALLENGE FOR BALKAN STUDIES? 269-289

Dejana M. Vukasović, Petar Matić

THE POWER OF "NORMATIVE POWER EUROPE“ DISCOURSE 291-310

Yorgos Tahtsidis

A CRITICAL ANALYSIS OF HOW THE LANGUAGE USED IN NEWSPAPER ARTICLES CAN LEAD TO FALSE PERCEPTION OF FACTS, FAULTY PUBLIC OPINION, AND FALSE POLICIES A CASE STUDY OF THE COVERAGE

OF THE REFERENDUM OF GREECE IN 2015. 311-336

Giuliano Bifolchi

THE NORTH CAUCASUS IN THE RUSSIAN POLITICAL DISCOURSE 337-350

Milena Pešić

DISCOURSE AND NATIONAL MYTHICAL NARRATIVE - ABOUT KOSOVO MYTH 351-373 
Marija Đorić

UNDERSTANDING VIOLENT EXTREMISM AND RADICALIZATION IN INSTITUTIONAL AND ACADEMIC DISCOURSE 375-392

Zoran Ćirjaković

THE IMPORTANCE OF THE CULTURALITY OF DISCOURSE FOR UNDERSTANDING THE GLOBALIZATION OF "UNIVERSAL" POLITICAL NORMS 393-420

Sanja Stošić

CATALONIA'S SECESSIONIST DISCOURSE 421-442 


\section{SADRŽAJ}

\section{POLITIČKA FILOZOFIJA I SHVATANJE DISKURSA}

Alpar Lošonc

DISKURZIVNA ZAVISNOST POLITIKE

SA KONFRONTACIJOM IZMEĐU

REPUBLIKANIZMA I NEOLIBERALIZMA

Lino Veljak

FILOZOFIJA IZMEĐU DISKURSA RELIGIJE I DISKURSA ZNANOSTI

Bogdana Koljević Griffith

POLITIKA, FILOZOFIJA, DEMOKRATIJA: FUKO I RANSIJER

Vesna Stanković Pejnović

MOĆ DISKURSA IZ FUKOOVE PERSPEKTIVE

Valerio Fabbrizi

POLITIČKI DISKURS I RAZUMNO

NESLAGANJE - ŠTA SUGERIŠE KONSTITUCIONALIZAM 
Ivan Matić

PRAVO DA SE GREŠI: TEORIJSKI I PRAKTIČNI ASPEKTI SLOBODE GOVORA U JAVNOM DISKURSU

II STUDIJE SLUČAJA I DISKURS

U SAVREMENIM POLITIČKIM PROCESIMA

Ruth Breeze

PRISTUP POPULISTIČKOM DISKURSU KROZ LINGVISTIKU: STEPENOVANJE U POLITIČKIM GOVORIMA 151-171

Raluca-Mihaela Levonian

SAMOLEGITIMIŠUĆE STRATEGIJE

U DISKURSU POLITIČKIH LIDERA: UPOREDNA ANALIZA DVA RUMUNSKA POLITIČARA 173-202

Evgeny A. Kozhemyakin, Svetlana V. Kryukova KONSTRUKCIJA NACIONALNOG IDENTITETA U POLITIČKOM DISKURSU: SLUČAJEVI PREDSENIČKIH NOVOGODIŠNJIH TV POSLANICA I OBRAĆANJA SAVEZNOJ SKUPŠTINI 203-235

Juraj Marušiak

PROMENA POLITIČKOG PEJZAŽA U CENTRALNOJ EVROPI OD $2010 . \quad$ 237-253 
Dobrivoje Stanojević, Lidija Mirkov

POPULISTIČKI STIL I LIDERSKA PATETIČNOST 255-268

Sanja Lazarević Radak

DISKURS O EVROPSKOM PUTU SRBIJE:

KRIZA ILI IZAZOV

ZA STUDIJE BALKANA? 269-289

Dejana M. Vukasović, Petar Matić

MOĆ DISKURSA O
“NORMATIVNOJ MOĆI EVROPE” $\quad$ 291-310

Yorgos Tahtsidis

KRITIČKA ANALIZA KAKO UPOTREBA JEZIKA U NOVINSKIM ČLANCIMA MOŽE VODITI VEŠTAČKOJ PERCEPCIJ, VEŠTAČKOM JAVNOM MNENJU I VEŠTAČKIM POLITIKAMA: STUDIJA SLUČAJA MEDIJSKE POKRIVENOSTI GRČKOG

REFERENDUMA IZ 1995. 311-336

Giuliano Bifolchi

SEVERNI KAVKAZ U RUSKOM POLITIČKOM DISKURSU 337-350

Milena Pešić

DISKURS I NACIONALNI MITSKI NARATIV - O KOSOVSKOM MITU 351-373 
Marija Đorić

SHVATANJE NASILNOG EKSTREMIZMA I RADIKALIZACIJE U INSTITUCIONALNOM I AKADEMSKOM DISKURSU 375-392

\section{Zoran Ćirjaković}

ZNAČAJ KULTURALNOSTI DISKURSA ZA RAZUMEVANJE GLOBALIZACIJE "UNIVERZALNIH" POLITIČKIH NORMI

Sanja Stošić

SECESIONISTIČKI DISKURS KATALONIJE 421-442 


\section{NOTES ON CONTRIBUTORS}

Bifolchi Giuliano is an Open Source Intelligence analyst specialised in the field of geopolitics, international relations, terrorism and security in the Middle East and the post-Soviet spaces. He holds a master's degree in Peacebuilding Management and International Relations from Pontifical University San Bonaventura, an M.A. and B.A. in History from the University of Rome Tor Vergata. Since 2016, Giuliano Bifolchi is a PhD candidate focusing his research project on the North Caucasus Federal District and the Russian strategies to manage and overcome socioeconomic problems in the region and to contrast local insurgency and terrorist groups. He is also the co-founder and director of the OSINT Unit of the Association of Studies, Research and Internationalisation in Eurasia and Africa (ASRIE).

Breeze Ruth is Senior lecturer in English at the University of Navarra, Spain, and combines teaching with research as a member of the Grad UN Research Group in the Instituto Cultura y Sociedad. Her most recent books are the co-edited volumes Essential competencies for English-medium university teaching (Springer, 2016), Evaluation in Media Discourse: European Perspectives (Peter Lang, 2017), Power, Persuasion and Manipulation in Professional Discourse (Peter Lang, 2017) and Imagining the peoples of Europe: Populist discourses across the political spectrum (John Benjamins, 2019).

Ćirjaković Zoran is a Lecturer at the Faculty of Media and Communications in Belgrade. He has been writing extensively on modernity and consequences of globalization in Sub-Saharan Africa and the Balkans. His current focus is on cultural translation and vernacularization of Euro-centric norms and ideas in the Non-Western and liminal contexts.

Đorić Marija is an Associate Professor at the Faculty of Media and Communications in Belgrade, Research Fellow at the Institute for Political Studies in Belgrade and Visiting Professor at 
the Faculty of Political Sciences in Belgrade. In her career, Marija participated in different projects as an expert/consultant in the field of security and extremism (OSCE, USAID). She holds a $\mathrm{PhD}$ from the Faculty of Political Sciences of the University of Belgrade. Marija published three books (Hooliganism: Violence and Sport, Right-Wing Extremism, Left-Wing Extremism), and more than 70 papers about extremism, terrorism, political violence, security, political theory and ideology. She also participated in over 40 scientific/expert conferences and round tables. Marija Djoric is a co-editor of journal "Science and Society", and a member of the Board of journals "Kultura polisa" and "Politička revija".

Fabbrizi Valerio serves as a postdoctoral Research Fellow at the Italian Institute for Philosophical Studies in Naples (Istituto Italiano per gli Studi Filosofici) and he is also adjunct Professor in Political Philosophy at the University of Rome Tor Vergata. His research focuses on theories and forms of democratic constitutionalism and on many topics of contemporary political theory: political liberalism... republicanism... theory of rights... constitutional law, legitimacy and legitimation; deliberative democracy. He has published numerous articles in important academic journals. His latest contribution, entitled "Constitutional Democracy in the Age of Populisms: A Commentary to Mark Tushnet's Populist Constitutional Law" has been recently published on Res Publica by Springer Publishing.

Koljević Griffith Bogdana graduated from The New School For Social Research, New York, where she gained her PhD in 2010. She has specialized in the field of contemporary political philosophy. She is the author of Biopolitika i politički subjektivitet (Službeni glasnik, Beograd, 2010), Kosovo, Evropa, demokratija (NSPM, Beograd, 2011), Biopolitika i savremeni svet (Zavod za udžbenike, Beograd, 2014), Twenty-First Century Biopolitics (Peter Lang International Publishing, Frankfurt, 2015), Između svetova (NSPM, Beograd, 2017), Demokratija savremenog francuskog poststrukturalizma (Zavod za udžbenike, Beograd, 2018), and co-author of Ustanak evropskih naroda (Filip Višnjić, Beograd, 2016) with Diego Fusaro. Bogdana Koljević Griffith is also author 
of over thirty articles in the field of contemporary political philosophy and political theory. She is a Research Fellow at the Institute for Political Studies in Belgrade. Between 2010 and 2012, she was the editor of the journal "Pravo i društvo", and in the period $2007-2013$, she was the editor of an interdisciplinary scientific journal "Nova srpska politička misao". Bogdana Koljević Griffith delivered lectures at a number of universities, including Columbia University, The New School, University of Oxford and University of Brasilia.

Kozhemyakin Evgeny is a doctor of philosophy and the head of department of communication studies, advertising and public relations, Belgorod National Research University, Belgorod, Russian Federation. In 2001 he defended the candidate degree thesis in philosophy, and in 2009, the doctoral dissertation on methodological issues of discourse analysis in cultural studies. He has several Russian translations of prominent sociologists published in the Russian Federation (e.g. Discourse and Power by Teun van Dijk). Since 2009 he is co-organizer of numerous conferences held in Belgorod University and other Russian universities on issues of media discourse studies. He is the founder and Editor-in-Chief of the e-journal "Contemporary Discourse Analysis". His scientific interests cover the issues of critical discourse analysis of mass media, social semiotics and multimodal discourse studies.

Kryukova Svetlana is a candidate in philology and Associate Professor at the Department of Communication Studies, Advertising and Public Relations, Belgorod National Research University, Belgorod, Russian Federation. In 2000, she defended her candidate degree thesis in linguistics on the issues of structural-semantic features of toponymical adjectives. Since then, she has been advising BA and MA students at the Faculty of Journalism, Belgorod National Research University, on the research topics linked to the linguistic and stylistic aspects of journalism, PR and marketing communications. She is experienced in judicial linguistic analytics and expertise. Her academic work refers to communicational pragmatics, critical linguistic analysis of media texts and public rhetoric studies. 
Lazarević Radak Sanja graduated in Ethnology and Anthropology. She holds an MA in Interdisciplinary Anthropology and $\mathrm{PhD}$ in Anthropology (Department for Interdisciplinary Anthropology, Faculty of Philosophy, University of Belgrade). She is employed at the Institute for Balkan Studies of Serbian Academy of Sciences and Arts (Belgrade, Serbia) as a Senior Research Fellow on the project Danube and the Balkans: Cultural and Historical Heritage. She is the author of the books: On the Border of Orient: The Representation of Serbia in English and American Travelogues between two World Wars, Mali Nemo, Pancevo, 2011; Discovering the Balkans, Mali Nemo, Pancevo, 2013; The Invisible Balkans: A Contribution to the History of Postcolonial Geographies, Mali Nemo, Pancevo, 2014; Film and Political Context: Reflections on Yugoslav and Serbian film, Mali Nemo, Pancevo, 2016; Yugoslav Cinema 1975-85 (in preparation for the press), co-editor of scientific magazines, editor-in-chief of editorial books, and author of numerous articles published in domestic and international journals.

Levonian Raluca-Mihaela is Visiting Lecturer for Romanian language at the University of Udine, Italy. Previously, she filled the positions of Adjunct Professor (2011-2016) and Visiting Lecturer (2010-2017) at the University of Calabria. After obtaining the Ph.D. title in 2009, she was awarded a postdoctoral research fellowship (2014 - 2015) by the University of Bucharest for a research project comparing contemporary political discourse in Romania and in Italy. She has authored articles in collective volumes and scientific journals in Romania and abroad. At present, she is a member of the editorial staff of the journals Interdisciplinary Journal of Family Studies and Metis. Ricerche di sociologia, psicologia e antropologia della comunicazione. Her research interests include pragmatics, discourse analysis and foreign language teaching.

Lošonc Alpar is a full Professor at the University of Novi Sad, Faculty of Technical Sciences, Department of Social Sciences. He is the correspondent member of the Serbian Academy of Sciences and Arts (SASA). His publications (inter alia) include numerous books and articles on political philosophy and theory. Some of his books are Sovereignty, Power and Crisis, 2006, Power 
as a Social Event, 2009, Resistance and Power, 2013, Anatomy of Commodity, 2017 - coauthor, Neoliberalism - Destiny or Choice, 2007 - coauthor, Merleau-Ponty’s Philosophy, 2010.

Marušiak Juraj graduated at Faculty of Philosophy of Comenius University in Bratislava in History - Slovak language and Literature (1994). Since 1996, he has been working as a Research Fellow at the Institute of Political Science, Slovak Academy of Sciences, where he obtained his $\mathrm{PhD}$ in 2003. His research is focused on the 20th-century history of Slovakia and on the issues of international relations in the region of Central and Eastern Europe after 1989. In 2002-2003, he completed the Lane Kirkland scholarship programme at Warsaw University, with a specialization in East European Studies. He has authored several articles in scientific journals and newspapers. He is the author of the monograph Slovenská literatúra a moc v druhej polovici pät'desiaty chrokov (Slovak Literature and the Power in the second half of the 50's; Brno, Prius 2001) and co-author of the monograph (Dez)integračná sila stredoeurópskeho nacionalizmu (The (Dis) integration Power of Central European Nationalism: A Study of the Visegrad Group Countries; Bratislava, Comenius University 2015). He has been a member of the Presidium of the Slovak Academy of Sciences since 2013.

Matić Ivan is a PhD candidate in Philosophy at the University of Belgrade, and works as Research Associate at the Institute for Political Studies, Belgrade. His main areas of interest include the social contract theory, classical republicanism and natural rights. He has published several articles and reviews, including "The General Will and the Jury Theorem" (Theoria, 2014), "Social Discord as the Foundation of Republicanism in Machiavelli's Thought" (Philosophy and Society, 2014), "The Concept of Mixed Government in Classical and Early Modern Republicanism" (Belgrade Philosophical Annual, 2016) and "Epistemic Proceduralism as a Model of Democratic Decision-Making" (Serbian Political Thought, 2017). 
Matić Petar is a Research Fellow at the Institute for Political Studies, Belgrade. In this scientific institution, he participated in the development and implementation of several scientific projects under the auspices of the Ministry of Education, Science and Technological Development. From 2007 to 2016, he was engaged as a teaching associate of the Faculty of Political Sciences, University of Belgrade, on the study course: Political System of Serbia. Since 2011, he has been Project Secretary at the Institute for Political Studies. He has been co-editor of the scientific journal Administration and Public Policy since 2015. He has published over forty scientific articles and two books. His scientific interests include institutionalism, political system, public policy and the role of discourse in public policy-making and creation of institutions.

Mirkov Lidija is a teaching assistant at University of Belgrade, Faculty of Political Sciences. She earned her PhD at the Faculty of Political Sciences in Belgrade. She worked as a reporter for several media with national coverage. Lidija Mirkov publishes papers about public discourse, language of the media, public speaking, journalistic stylistics and media genres.

Pešić Milena works as Research fellow at the Institute for Political Studies in Belgrade. Her scientific research is focused on the multidisciplinary field of Communication, Cultural Studies, and Politics. Central themes of her articles include the issues of national and cultural identity; discourse and discourse analysis; the public; the public sphere; public opinion; media, media audiences, media production of meaning. She has published the monograph study: Liberty and Public Sphere (co-author Aleksandar Novaković, Institute for Political Studies, Belgrade, 2008). She holds MA and $\mathrm{PhD}$ degrees from the Faculty of Political Sciences in Belgrade, Department of Cultural Studies.

Stanković Pejnović Vesna is a Research Fellow at the Institute for Political Studies in Belgrade. She is an author of three books: Macedonia at the Crossroads between Europeanisation and Balkanisation (Cibej Press, 2013), Political Philosophy of Friedrich Nietzsche (Mediterran Publishing, 2014), Balkan Illusion 
and European Perspective (Lambert Publishing, 2015). She has published articles in Global Journal, Creativity Studies, Synthesis Philosophica, Filozofska Istraživanja, Logos and in other journals and newspapers, as well as collections. She is a member of the Advisory board for the Research Institute for European Studies. She was former Director of international projects „Offices for human rights“ in Zagreb and Osijek, and „Returning “ supported by USAID. Vesna Stanković Pejnović holds an M.A. degree in History from the University of Zagreb University and a $\mathrm{PhD}$ in Philosophy from the University of Skopje. She is co-editor of Macedonia, Social, Political and Economic issues, 2017, NOVA science publisher.

Stanojević Dobrivoje is a full Professor at the University of Belgrade, Faculty of Political Sciences. He earned his $\mathrm{PhD}$ at the Faculty of Philology in Belgrade. He worked as an editor of literature for Students' City Cultural centre in Belgrade. He was also Editor-in-Chief of a local TV station - TV Smederevo. Prof. Stanojević publishes papers and books about language in the media, but also literature and poetry. Some of his published books include: Media eristics and public discourse, Rhetoric of Golden Fleece, Socrates practices evanescence, Stylistics of Golden Fleece, Form or not about Love, Rhetoric and Politics.

Stošić Sanja works as a Research Fellow at the Institute for Political Studies in Belgrade. Until 2018, she worked at the Faculty of Diplomacy and Security as an Associate Professor of Spanish Language. Since completing her PhD in 2016, her research has been focused on historical, socio-economic and political issues, with particular reference to Spain and Latin America, as well as the countries of the Asia-Pacific region.

Tahtsidis Yorgos is a PhD candidate in Applied Linguistics at the Hellenic American University and holds a Master of Arts degree in International Relations from Georgetown University while his Bachelor degrees are in German Literature and International Studies with a focus on Political Science and Diplomacy. $\mathrm{He}$ teaches English, German, and Greek at Berlitz Virtual Classroom 
to executive personnel of multinational corporations - such as Shell, German Telekom, Federal Express, IKEA - and international organizations such as the World Health Organization.

Veljak Lino is a full Professor at the Department of Philosophy, Faculty of Humanities, University of Zagreb and director of postgraduate studies in philosophy at the same university. He is also President of National Council for Philosophy and Theology. His main books are: Marxism and the Theory of Reflextion (1979), Philosophy of Practice of Antonio Gramsci (1983), Horizon of Metaphysics (1988), The Crossroads of Epoch (1990), Between Ontology and Philosophy of History (2004), Contributions to the Critique of False Alternatives (2010), Introduction to Ontology (2019), The Issues of our Time (2019). His recent publications in English are: "Tendencies of De-secularization in Serbia and Croatia" (with Staša Zajović, in M. Hellie-Lucas, ed., The Struggle for Secularism in Europa and North America, London/Dakar/ Lahore 2011), "Hegel and Marx in the Times of Globalization" (Facta universitatis. Series. Philosophy, Sociology, Psychology, and History, 1/1014), "The World as Human-Produced Worlds in the Philosophy of Giambattisata Vico" (with Marija Selak, Synthesis Philosophica, 2/2015), "Philosophy in Times of Regression" (Dialogue and Universalism, 2/2016).

Vukasović Dejana is a Senior Research Fellow at the Institute for Political Studies, Belgrade and a Visiting Professor at the Faculty of Political Sciences of the University of Belgrade. She graduated from the Faculty of Political Sciences of the University of Belgrade (Department International Relations). She holds LLM in European Union Law from the University of Lorraine (ex-Nancy 2), France, as well as postgraduate diploma in European Civilization from the University of Lorraine. She also holds PhD in European Union Law from the Faculty of Law, Economics and Management of the University of Lorraine. During her academic career, she has published numerous scientific papers in domestic and international journals, as well as three monographs (one of them is her doctoral thesis published in French language). Her research interests include EU and global governance, identity of 
the EU, poststructuralism in international relations and European studies, alterity, Western Balkans, Common Security and Defence Policy. 


\section{ACKNOWLEDGMENTS}

The publication of the volume "Discourse and Politics" is a result of collaboration occasioned by the 50th anniversary of the Institute for Political Studies in Belgrade.

We would like to thank all contributors for their patience and understanding in the process of preparing this volume for publication. We also thank them for their valuable contributions.

Finally, we are grateful to our colleagues from the Institute for Political Studies in Belgrade for their support.

Dejana M. Vukasović, Petar Matić, editors 
I

\section{POLITICAL PHILOSOPHY AND} UNDERSTANDING OF DISCOURSE 
UDC 321.01

Valerio Fabbrizi*

\section{POLITICAL DISCOURSE AND REASONABLE DISAGREEMENT - WHAT CONSTITUTIONALISM SUGGESTS}

Abstract

Reasonable disagreement is one of the most critical issues in contemporary political philosophy, especially within liberal-democratic constitutionalism. In emphasising the role of disagreement in the relationship between discourse and politics, many scholars such as Jeremy Waldron and Richard Bellamy - against the background of the Rawlsian idea of "reasonable pluralism" - defend the thesis of moral disagreement as the core of political deliberation. By refusing the idea of neutrality, these authors maintain that political discourse cannot be established by simply removing our moral disagreement on political values. This essay engages the issue of "discourse and politics" by focusing on some relevant topics: the deliberative conception of democracy; the Rawlsian idea of public reason as a forum for deliberation and discourse; the fact of disagreement and its influence on the deliberative process.

In order to investigate such issues, the paper follows three ways. First, it aims at examining John Rawls' idea of public reason, by presenting it as a tool to

* Research Fellow, Italian Institute for Philosophical Studies in Naples and adjunct Professor in Political Philosophy, University of Rome Tor Vergata. 
resolve reasonable disagreement in the context of constitutional essentials. The second section deals with reasonable disagreement from a liberal point of view, by trying to focus on some critical remarks which Bellamy raises against Rawlsian political liberalism. The third section briefly analyses Waldron's arguments in defence of reasonable disagreement, as a critique of the deliberative model of democracy. From this perspective, Waldron presents deliberative democracy's failure in considering political dissent and moral disagreement as two problematic aspects of democracy.

Keywords: discourse and politics, reasonable disagreement, public reason, neutrality, consensus.

\section{INTRODUCTION}

Reasonable disagreement is one of the most debated issues in contemporary political philosophy. Generally speaking, reasonable disagreement is an intersubjective matter, as Samantha Besson correctly remarks, it opposes two or more people in a context of deliberation and intellectual exchange. Hence, Besson elucidates that "disagreement results from real differences of judgment or the "diversity of opinions" among members of a political community" (Besson 2005: 20).

Additionally, disagreement primarily concerns general principles, different conceptions of justice and, also, the constitutional essentials and not personal or group interests. Finally, reasonable disagreement opposes different opinions and views about justice and rights, openly and sincerely expressed in a public political discourse. On this line, Besson adds that such opinions "ought to be distinguished from mere moral differences (...) and differences in holding conflicting values" (Besson 2005: 21).

Citizens frequently disagree on many issues of social and political life, confronting themselves on different and sometimes irreconcilable moral and political grounds. Disagreement can concern different conceptions of justice, different views about funda- 
mental values and the ways in which these values and rights should be protected. In this respect, Besson remarks the importance of distinguishing among "moral" disagreement (which affects value judgements) and "political" disagreement, which takes such values into account when meeting political matters. Nevertheless, a further definition of disagreement should be traced: disagreement about the law emerges as the main sort of political and moral disagreement. This depends on the fact that "it is a type of political disagreement since law may be regarded as an "offspring of politics" (Besson 2005: 46).

In the lights of the moral disagreement, people can reasonably defend a "political" variety of constitutional democracy, according to which fundamental rights and principles are supposed to be better protected by parliaments and majority rule; others can instead reasonably defend a "legal" account of constitutionalism, by considering courts as necessaryinstitutions to protect fundamental rights from the risks of a constitutional majoritarianism. ${ }^{1}$

More generally, reasonable disagreement involves a debate concerning its role within constitutional democracy and two different approaches can be identified: on the one hand, many commentators (Jeremy Waldron and Richard Bellamy, at first) consider as simply impossible to set aside or trivialize disagreement, by remarking its fundamental role for the democratic process. On the other hand, liberal theorists such as John Rawls and Charles Larmore defend a model of democracy which adopts the principle of neutrality as the only way to make fair and equal decisions about justice and political issues.

\section{PUBLIC REASON AND DISAGREEMENT IN JOHN RAWLS' POLITICAL LIBERALISM}

The core question in John Rawls'Political Liberalism asks "how is it possible that there may exist over time a stable and just

1 This difference concerns, in a broader sense, the debate between legal and political models of constitutionalism. The first one - proposing a dualist idea of democracy - distinguishes the level of constitutional politics from the level of normal politics, in order to defend the democratic role of constitutional courts and the legitimacy of judicial review. Political constitutionalists, by rejecting the idea of a judicial control over legislative power by courts, defend a majoritarian form of monist constitutional democracy in which there is no separation between normal and constitutional politics. On this point see B. Ackerman (1991), R. Bellamy (2007). 
society of free and equal citizens profoundly divided by reasonable though incompatible religious, philosophical and moral doctrines?" (Rawls 1993: XVIII).

The Rawlsian response focuses on the idea that disagreement arises from the so-called "circumstances of justice", which are the combination between the principle of "moderate scarcity" and "moderate self-interest". At the same time, Rawls stresses that political liberalism proposes the idea according to which a well-ordered society is commonly characterized by a reasonable pluralism which implies to reject any form of liberal perfectionism.

In Rawls' words, the cornerstone of political liberalism lies on the liberal principle of legitimacy, which states that "our exercise of political power is fully proper only when it is exercised in accordance with a constitution the essentials of which all citizens as free and equal may reasonably be expected to endorse in the light of principles and ideals acceptable to their common human reason" (Rawls 1993: 137).

The key point of the liberal principle of legitimacy affirms that the constitutional essentials on which the political power is grounded can be considered as legitimate only when they are accepted by all citizens, independently of their individual comprehensive doctrines. In the lights of such a principle, political liberalism assumes two key theses: the first points out that the constitutional essentials and the legitimacy of the political power depend on specifically "political" values; the second thesis involves the idea of an overlapping consensus, which entails that the political power and the constitutional essentials should be articulated independently from any particular comprehensive doctrine. This is what Rawls defines as a "political conception of justice".

The Rawlsian idea of a well-ordered society is based on the idea of "reciprocity", that can be distinguished into two versions: a weak reading and a strong reading. Under a weak reading, reciprocity requires that a person should be prepared to publicly justify only those principles according to which one acts in terms "others might reasonably accept" by sharing a common moral point of view from within the common human reason (Reidy 2006: 24). 
The weak reciprocity means that citizens admit to reasonably disagree over moral or ethical issues when they reasonably defend their opinions about such issues, whilst they seek a common and shared point of view, but disagreement persists. Conversely, strong reciprocity demands "more than that we act toward our fellow citizens in political life in accord with and from principles they could reasonably accept" (Reidy 2006: 26). In this sense, strong reciprocity presupposes that, in our political life, we act in accordance with principles that the others could reasonably affirm and not reasonably reject.

The main difficulty with reciprocity lies in shifting from the weak to the strong version since, as Reidy concedes, "while the counterfactual aspect of "could" renders the weak could reasonably affirm formulation of reciprocity virtually toothless (since so many things "could" reasonably be affirmed) it renders the strong reading virtually ruthless" (Reidy 2006: 27). By contrast, the strong version - the so-called "could not reasonably reject thesis" - contains an idea of reciprocity which demands that "no citizen could reasonably reject those terms now or at any future point in time" (Reidy 2006: 27).

We cannot explore political discourse in Rawlsian terms without distinguishing between reasonable and rational actors. Reasonable persons are those who are willing to accept fair terms of cooperation and, at the same time, to propose such terms and principles to create a system of social and political equality in a context of reciprocity. Reasonable persons are not inclined to pursue general good as such, but they aim to follow the principle of fair cooperation on terms that all can accept. Conversely, rational individuals accept to participate into social cooperation only on the basis of their personal advantage or benefit; as Rawls highlights, "they are ready to violate such terms as suits their interests when circumstances allow” (Rawls 1993: 50).

Rationality and reasonableness are two complementary characteristics of human being, though they are two distinct ideas: the reasonable has the disposition and the willingness to cooperate with others for the common good, while the rational pursues only his/her own personal aspirations and goals. Nonetheless, Rawls remarks that, on the one hand, rational agents are not merely self-in- 
terested individuals, since rationality does not imply interests in benefits to themselves but it can be interested in defending many kinds of affections or passions, such as love in a broader sense; thus, rational actors are ready to make everything to protect and defend such feelings.

Similarly, reasonable agents cannot be defined as merely "altruistic", if it means to exclusively act for the interest of the others, since everybody holds rational ends and life scopes which cannot be set aside, though being disposed to fairly cooperate with all the others. This means that, as Rawls claims, "reasonable and the rational are taken as two distinct and independent basic ideas. They are distinct in that there is no thought of deriving one from the other; in particular, there is no thought of deriving the reasonable from the rational" (Rawls 1993: 51).

Nevertheless, rationality and reasonableness are complementary; it implies that both the rational and the reasonable cannot stand without the other: merely reasonable individuals would not have personal ends and scopes to promote though social cooperation; conversely, purely rational agents would lack of a sense of justice, by promoting only their personal ends and ignoring the spirit of cooperation.

Additionally, reasonable is "public" in the way the rational is not; reasonableness allows political actors to participate into the public sphere in a condition of cooperation with others, by promoting fair terms of the cooperation itself and by accepting the terms proposed by others. Thus, being reasonable imposes to think about our fellow citizens with respect, in the lights of the reasonable disagreement, but having the purpose to find a common ground when moral and political issues are at stake.

However, the peculiar aspect of reasonable agents is that they are inclined to recognize and respect the so-called "burdens of judgment" which are the sources or the causes of reasonable disagreement between reasonable persons, by accepting their effects on the legitimate exercise of public reason; Rawls identifies six stages of the burdens of judgment, by listing them as it follows:

1. The evidence - empirical and scientific - bearing on the cases is conflicting and complex, and thus hardtop assess and evaluate; 
2. Even where we agree fully about the kinds of considerations that are relevant, we may disagree about their weight, and so arrive at different judgments;

3. To some extent all our concepts, and not only moral and political concepts, are vague and subject to hard cases; and this indeterminacy means that we must rely on judgment and interpretation (and on judgment about interpretations) within some range (...) where reasonable persons may differ;

4. To some extent the way we assess evidence and weigh moral and political values is shaped by our total experience, our whole course of life up to now; and our total experiences must always differ;

5. Often there are different kinds of normative considerations of different force on both sides of an issue and it is difficult to make an overall assessment;

6. Any system of social institutions is limited in the values it can admit so that some selection must be made from the full range of moral and political values that might be realized (...) In being forced to select among cherished values, or when we hold to several and must restrict each in view of the requirements of the others, we face great difficulties in setting priorities and making adjustments. Many hard decisions may seem to have no clear answer (Rawls 1993: 56-57).

Reasonable agents know that the burdens of judgment impose limits and constraints on what can be reasonably justifiable in front of the others; consequently, reasonable persons accept to disagree with their fellow citizens, by considering as unreasonable to use the political power to overcome moral disagreement by restraining non-unreasonable comprehensive doctrines.

The burdens of judgment thus represent the constraints over the collective exercise of the common human reason and their task is to motivate the existence of a deep reasonable disagreement among citizens; in this sense, the burdens of judgment are the pillars on which a fair and open political discourse can be settled within democratic regimes. 
Many authors (Cohen 2003; Ferrara 2014) have described Rawls as a theorist of deliberative democracy and, to some extent, they seem to be right. Deliberative democracy, as Rawls conceives it, focuses on the idea that the public political debate, which aims at enabling the exercise of collective power, is an expression of the exercise of citizens' common reason, a form of moral argument deriving from reason and shaped on the idea of a democratic society of free and equals.

Under a deliberative banner, democratic politics- to be legitimate - needs to be structured on moments of public debate, in which citizens can exchange their reasons and ideas in a condition of equality and free speech. As Alessandro Ferrara underlines, "without this moment of discourse - broadly understood as a dialogical exchange under conditions of good faith, equality and reciprocity - politics would just be based on arbitrary force, the contingencies of power or the oscillation of popular sentiment" (Ferrara 2014: 32).

Deliberative democracy, properly understood, holds three key points: 1. An "object of deliberation" as its core issue; 2 . The idea of the existence of this "object" leads us to assume the existence of a "deliberative body", namely a subject of deliberation within which a collective discussion takes place; 3 . The third point poses the existence of a "deliberative process", within which a free and open exchange of reasons among the participants in the deliberative process takes place.

The Rawlsian deliberative account of democracy proposed adopts the idea of public reason as its pillar; in Rawls' view, public reason is a deliberative forum in which citizens can confront their positions and participate into the political discourse from a position of equality. In Larmore's words, "we honor public reason when we bring our own reason into accord with the reason of others, espousing a common point of view for settling the terms of our political life" (Larmore 2003: 368).

The idea of public reason is deeply connected with the so-called ideal of publicity, a tool of representation which entails the idea according to which we tend to adopt the principles of justice by the fact that we believe that our fellow citizens will do the same. The core of the ideal of publicity lies on the idea that the 
social contract, on which our society is based, is built on a shared system of justice.

Publicity consists of three stages. The first one states that a democratic society should be governed in accordance with the principles of justice. In this first step, citizens accept such principles and believe that the others will do the same and this mutual trust is publicly recognized. The second one implies, in Rawls' terms, "the general beliefs in the light of which principles of justice can be accepted" (Rawls 1993: 66). These beliefs mainly concern the human nature and the way in which our socio-political institutions work; in the second stage, citizens share their beliefs and views, by participating into political discourse and a process of public reasoning to present their own views and eventually support those of others. The third step relates to the idea of a full justification of the political conception of justice. As Rawls points out, "this justification includes everything that we would say when we set up justice as fairness and reflect why we proceed in one way rather than another". (Rawls 1993: 67)

When, in a well-ordered society, all these three stages of publicity are fulfilled, the so-called full publicity condition is finally satisfied. This condition occurs only when all the characteristics of a well-ordered society are publicly disclosed and subjected to a fair and public political discourse. Indeed, the full publicity condition does not depend only on its public acceptance, but also when it is justified in a way that everybody might embrace and share such a condition.

Public reason is the basic element of any constitutional democracy; its form and content represent the main arguments of the Rawlsian conception of democracy. As Rawls claims, any democratic society is characterized by the so-called fact of pluralism, which consists in the existence of various facing reasonable comprehensive doctrines. Within public reason, citizens well know the impossibility to reach an agreement on the basis of their conflicting comprehensive doctrines; thus, in a condition of reasonable pluralism, public reason aims to facilitate the political discourse by accepting all the comprehensive doctrines, as long as they do not conflict with the constitutional essentials and with the idea of public reason itself. The application of public reason within our 
analysis of "discourse and politics" leads us to distinguish five fundamental features of such a tool:

1. Public reason should always focus only on premises which are shared and accepted by all citizens;

2. Public reason only concerns issues of basic justice and only refers to the constitutional essentials;

3. Besides public reason, Rawls postulates the existence of other forms of political discourse, different from public reason but equally legitimate: declaration, conjecture, andwitnessing. In the case of the declaration, we are called to declare our own comprehensive doctrine, by presenting them to our counterparts. Conjecture, instead, calls us to "argue from what we believe (...) are other people's basic doctrines $(. .$.$) and try to show them that (...) they can still$ endorse a reasonable political conception that can provide a basis for public reason" (Rawls 1993: 465-466).

4. An argument stemming from issues of basic justice, by respecting the constitutional essentials and does not relate to these three kinds of discourse, fits within the public reason only if it takes place within the so-called public political forum, which is different from the so-called background culture.

A public forum is a context of argumentation in which a decision eventually must be made. This distinction is not the same as the distinction between the sphere of political decision making and the public sphere in Habermas. For the public forum includes not only the arguments taking place among office holders in legislative, executive, and judicial institutions when deliberation about the relevant matters is at stake but also deliberation in the larger citizenry when voting "in elections when constitutional essentials and matters of basic justice are at stake," arguments offered by "members of political parties" and candidates in their campaigns. In the "background culture," instead, we find arguments exchanged on the basis ofnon-public reasons in churchesand universities, scientific societies and professional groups (Ferrara 2008: 64-65).

A further feature of public reason distinguishes between inclusive and exclusive conceptions. According to the inclusive 
version, citizens are able to propose within the political discourse also those political values which refer to their comprehensive doctrines, provided that these values contribute in enforcing and enhancing the ideal of public reason itself. For the exclusive version, citizens can never present arguments from their own comprehensive doctrines when within public discourse fundamental political issues are at stake.

Within the public political forum, three different kinds of discourse can be identified: the first is the discourse delivered by judges in enacting their sentences - the judges of the Supreme Court, for instance; the second one is the discourse of the elected representatives, especially when holding an office; the third is the discourse of the candidates for such institutional offices or of their mentors or their electoral campaign's managers.

Within this framework, public reason develops within the public political forum and it is applied to parliaments and to their elected members; to government and to any other political or elected assembly. Following the Ackermanian dualist definition of constitutional democracy ${ }^{2}$, Rawls refers to the Supreme Court as the "exemplar of public reason", since the justices should always be able to publicly justify their decisions about laws and legislative acts enacted by parliaments, in the light of the constitutional essentials and the principle enshrined by the Constitution.

Public reason states that, when a reasonable decision about the constitutional essentials is made, reasonable citizens are not necessarily supposed to agree with such a decision; Rawls does not believe that reasonable and rational actors agree on all the decisions concerning the constitutional essentials or that they share the same concerns or opinions about legislative acts. Hence, the burdens of judgments help us to recognise the persons are often in a condition of reasonable disagreement both about the reasonableness of the

2 Bruce Ackerman defines the so-called "dualist" model of democracy by distinguishing two different levels of democratic decision-making: on the one hand, there is the "higher" lawmaking, which corresponds to the level of the Constitution and which is embodied by we, the People; on the other hand, we have the so-called "ordinary" lawmaking, which instead corresponds to the ordinary legislation carried on by representatives in the Congress or in parliament. At the same time, dualist democracy separates between two kinds of politics: "constitutional" politics, which occurs rarely and calls the people to express their voice about the fundamental principles and "normal" politics, which instead occurs daily and that is in the hands of the electorate, represented by the legislative members. About this issue see Ackerman 1991. 
outcomes of a political discourse and on what they should consider as "morally" reasonable with respect to their comprehensive doctrines.

In addition, Rawls emphasises that differently from "moral" disagreements - disagreement about politics affects the political values that individuals accept and share as free and equal members of society. Accordingly, Samuel Freeman has correctly proposed to distinguish between political and moral accounts of reasonable disagreement.

Agreement on political values of public reason is crucial for the political autonomy of free and equal citizens; it is not essential that citizens always agree on laws and the appropriate resolution of disputes within public reason. General agreement among all reasonable citizens is only to be had on a few fundamental matters. Among these are most of the political values that count as public reasons, the guidelines for public reason, and the basic requirements of a liberal political conception of justice. For much of his career, Rawls hoped that he could show how it is possible that reasonable free and equal moral persons could come to generally agree upon justice as fairness as a regulative conception of justice. But he finally gave up on this ideal of a well-ordered society, once he fully realized the implications of the burdens of judgment (Freeman 2007: 410).

To conclude, Rawls addresses the issue of reasonable disagreement and discourse in politics by presenting public reason as the natural framework within which a moment of political public deliberation can take place.

\section{LIBERAL DEMOCRACY AND THE FACT OF DISAGREEMENT}

David Archard has rightly noted that disagreement essentially derives from pluralism and it is deeply connected with the idea of public reason. As Archard underlines "we could contrast two views of the political condition. The first sees the problem as one of philosophical disagreement [...] The second sees the problem as a conflict of material interests that derives from a competitive struggle for self-advantage and access to goods and power" (Archard 
2001: 208). Thus, social conflict and political disagreement arising from socio-economic factors can be solved through an agreement on principles of justice; by the contrary, such agreement cannot help us to solve moral disagreement.

On this line, Richard Bellamy argues that the principles of justice cannot operate as a general framework, with ordinary democratic procedures, being perfectly acceptable as long as they do not risk to violate basic liberties. As Bellamy writes, "when competing conceptions of justice and rights are in play and are themselves in competition with other goods and values, then it becomes necessary to have political procedures that enable such disputes to be resolved in a manner that takes into account the interests and ideals of those concerned" (Bellamy 1996: 13).

In Liberalism and Pluralism, Bellamy notes that Rawls implants the so-called "fact of pluralism" within the framework of the burdens of judgment, by being "agnostic on the issue of whether pluralism is real or simply an appearance beyond which we are unlikely to go" (Bellamy 1999: 8). Thus, for Bellamy, the burdens of judgment set in superable obstacles in achieving an agreement on the better way to lead life. Bellamy adds that these limitations are not the result of a bad logic, narrow-mindedness or mere self-interest, but they are only the result of what we can reasonably demonstrate (Bellamy 1999: 43).

Accordingly, in pluralist societies moral disagreement is a substantially unavoidable condition; the crucial point in endorsing disagreement suggests that it does not arise from a rejection of reasonable discussion, or to an unreasonable approach to fundamental issues. Theorists of disagreement contend that liberals à la Rawls, in proposing neutrality principle as the way to resolve controversies, fail in affirming that, on the one hand, disagreement originates from irrationality or mental closure and, on the other hand, that disagreement is, tout court, the wrong way of reasoning.

In discussing reasonable disagreement, Robert Talisse suggests distinguishing between the so-called "non-convergence thesis" and the "equal reasonableness". The first thesis implies that the free and equal exercise of individual reason does not fall within the general convergence of all individuals on a particular comprehensive doctrine. As Talisse stresses, Rawls recognizes the 
principle according to which our public debate on natural sciences can lead us to a convergence of opinion "at least in the long run"; however, Rawls denies the possibility that such convergence could be achieved on philosophical, religious or moral principles or constitutional essentials. Rawls denies that rational and free citizens will eventually come to agree upon a single comprehensive doctrine, even in the long run. Although disagreement with regard to scientific theories may be temporary, disagreement with regard to comprehensive views can be overcome only by oppression. Disagreement is, therefore, a "permanent" feature of a free society (Talisse 2003: 178).

According to the second thesis -the "equal reasonableness" -our different comprehensive doctrines - though sometimes incompatible each other - are to be generally considered as equally coherent with the exercise of our common human reason. In this vein, disagreement should not be considered as a "matter of dogmatism or unreasonableness"due to the fact that when the full and proper exercise of human reason does not identify with a specific and particular comprehensive doctrine, our disagreement on moral and philosophical matters will be considered as purely "reasonable".

There is a plurality of fully reasonable comprehensive doctrines, such that doctrines that are logically incompatible may each be fully reasonable. In this sense, there is not simply widespread a permanent disagreement among people, but widespread and permanent pluralism with regard to philosophical, moral and religious essentials about which people might disagree (Talisse 2003: 178).

Scholars such as Waldron, Bellamy and Albert Weale identify the so-called "circumstances of politics" as a key issue. The "circumstances of politics" arises intwo main aspects: the first relates to the fact that our contemporary society is characterized by a deep reasonable moral disagreement. In such a condition, we disagree on many aspects of social and political life, and we put our particular conception of justice into play. The second aspect is that - despite this wide disagreement - we need to make decisions which allow the citizens to live and cooperate together as free and equals.

As Bellamy writes, "circumstances of politics are circumstances where we disagree about both the right and the good, yet nonetheless, require a collective decision on these matters. Conse- 
quently, the constitution cannot be treated as a basic law or norm" (Bellamy 2007: 5). This means that the constitution should be considered as a "political" issue which is to be subject to public political debate.

From the Rawlsian perspective, reasonable disagreement can only concernour comprehensive doctrines and not the constitutional essentials, which instead fall into an overlapping consensus. For Rawls, fundamental rights and principles and the most divisive issues should be always left outside the ordinary political discussion; at the same time, the interpretation of fundamental principles and of the basic rules concerns the scope of public reason and of the Supreme Court, that Rawls defines as the "exemplar of public reason"(Rawls 1993: 231-239).

In Bellamy's view, the circumstances of politics allow us to assume the commitment to equality of concern and respect in a way that satisfies the condition of the republican non-domination. In this vein, Bellamy argues that "a system of equal votes and majority rule complies with this criterion by offering a procedural form of public reasoning that provides a fair means for 'hearing the other side'. Competition between political parties further reinforces this system by promoting the responsiveness of political agents to their citizen principals and of citizens to each other" (Bellamy 2007: 259). Reasonable disagreement entails that modern pluralist societies are characterized by different worldviews and competing methods and solution to cope with this disagreement. Simon Caney indicates three possible solutions to this matter: the first is a so-called "institutional" solution, according to which, a way to cope with moral disagreement is to create political institutions in order to recognize and accept moral conflict as a vital element of our contemporary society, instead of rejecting it as a negative aspect.

As Caney reiterates, the first solution aims to create political procedures in order to give citizens the opportunity to properly defend their own worldviews under the equality principle and to gain the support of their fellow citizens. Thus, finally, political institutions are designed to regulate such disagreement in an equal and legitimate way.

The second solution - the so-called avoid anceresponse takes into account those considerations which citizens and their 
representatives should keep in mind when deciding about political issues. By recalling Rawls, Caney writes that "those who hold political office should practice this method of avoidance. Clearly, the neutralist position falls into this category since it forbids citizens and politicians from drawing on their beliefs about the good when passing legislation. Certain considerations [...] should not shape or influence political measures" (Caney 1998: 20).

The third solution is the so-called cultural response. It concerns virtues and fundamental character traits that people hold and propose when they disagree. Thus, it means that citizens who disagree should adopt certain fundamental norms and principles of justice, treating whom they disagree with civility and respect. Disagreement can "culturally" be reduced "by avoiding contempt for others, arrogance, boorishness and insulting language" (Caney 1998: 20). By assuming the second solution as the bestone, and by defending an anti-perfectionist approach on justice, neutrality seems to be better equipped in order to respond to reasonable moral disagreement. Caney presents three further issues:

1. Reasonable disagreement does not concern principles of justice as a whole; thus, it follows that there is always a basic consensus on certain political values and ideals, such as - for instance - the respect for fundamental human rights or the respect for democratic principles such as free elections or democratic representation. The real disagreement concerns specific issues of justice: in this line, people diverge,for example, in their views about distributive justice; in the forms of punishment; in the legitimacy of the death penalty; in the forms of judicial activism over constitutional matters and so on.

2. Due to reasonable disagreement, principles of justice cannot be directly enacted by the State and this means that the State is prevented to impose just policies. Caney consequently admits that there is a cost to pay in terms of State-action when we establish that principles of justice should be acceptable to all reasonable citizens.

3. The principles of justice might be reasonably questioned by people; accordingly, the principles of distributive justice may be legitimately rejected by reasonable people simply because they disagree about the aims. Caney supports the thesis for which it 
should be extremely implausible to argue that the State should not engage in enacting just policies.

Lars Vinx highlights that disagreement can be legitimately limited in the sense that there may be a certain conception of democracy and rights which cannot be reasonably subject to contestation or disagreement. As he notes, "if there is a defensible core-conception of democratic integrity that must be satisfied before democratic procedure can legitimately arbitrate the remaining disagreements about rights, there would seem to be no conclusive reason, from a democratic point of view, not to constitutionally entrench it and to have it enforced by the courts" (Vinx 2009: 594).

Bellamy rejects this analysis, by remarking that there is no fundamental moral principle, valid for all citizens, at the base of democratic legitimacy and that cannot be subject to public discussion as matters of reasonable disagreement. In his view, the only legitimate way to choose the fundamental principles is to give voice to disagreement, enhancing it through the majority rule.

\section{ON JEREMY WALDRON'S DEFENCE OF REASONABLE DISAGREEMENT}

In his major work, Law and Disagreement (1999), Jeremy Waldron focuses on the premise according to which politics primarily concerns disagreement. His question asks how law and politics can claim authority over citizens while recognising and enhancing a widespread reasonable moral disagreement about justice and constitutional essentials.

Within this framework, Waldron shares with Ronald Dworkin that disagreement can reasonably pertain to the idea of democracy itself, to what it does require and to what it is implied in such a notion. In this perspective, citizens are supposed to disagree about basic principles and fundamental issues such as the right to vote, the idea of political participation, the issues on which a common decision is required, the consequences of such issues on each of the social groups which form part of the community, the relationship between minority and majority groups and so forth. What Waldron emphasises is that "even if they agree that democracy implicates 
certain rights, citizens will surely disagree what these rights are and what in detail they commit us to" (Waldron 1999: 294).

In Waldron's view, reasonable disagreement implies that, in a constitutional democracy, constraining majoritarian will - throughjudicial review, for instance - represents an allegedly unjustified and illegitimate procedure. On this point, David Estlund notes, Waldron claims that "majoritarian processes cannot be subordinated to any particular account of justice, or rights, or even democracy without enshrining some view that is open to reasonable objection" (Estlund 2000: 112).

Waldron then assumes that disagreement is an indisputable condition of contemporary societies: people disagree, first of all, about the nature of rights, about the possible moral foundation of rights. Such a disagreement concerns "what rights we have; what they are rights to and what they are based on" (Waldron 1999: 11). Moreover, Waldron points out that, though assuming a Rawlsian overlapping consensus as the basis of democratic theory, we will always hold a strong disagreement about the implications of such a consensus and on what such a consensus really entails.

"Does", Waldron asks, "the US Bill of Rights imply a right to privacy which in turn generates a basis for striking down laws that restrict abortion?" Or, as Waldron insists, "does the Second Amendment of the US Constitution require legislatures to permit private individuals as well as well-regulated state militias to carry assault weapons?" (Waldron 1999: 12). The crucial point here is that these issues generate a radical and intractable disagreement about them, for their interpretation and, moreover, for the implications they might have in our lives.

In defending reasonable disagreement, Waldron assumes a critical position against deliberative democracy, by contesting the thesis according to which the real aim of democratic debate is to achieve a reasonable consensus by setting aside disagreement through neutrality principle. Waldron argues that this ideal consensus tends to "present reasons that [...] the other should accept, and for two or more people to persist in argument is for them to notice and pursue the possibility that in the end, the same considerations will convince them all" (Waldron 1999: 91). 
In his opinion, deliberative democrats emphasize that disagreement is a detrimental and problematic aspect of democracy, underlying, at the same time, that disagreement is actually the failure of deliberative process which is reflected in a weak and narrow consensus. For Waldron, deliberative democrats try to delegitimise voting decision and majority rule legislation in several ways. First, the deliberative model may be confined, in its application, only to those who share a common understanding and who consider politics as the way to clarify what this shared understanding is. Secondly, the deliberative model may be confined to certain areas of politics that deliberative theorists consider as more "consensual" (constitutional essentials or the idea of justice, for instance). Thirdly, deliberative theorists may affirm that there is something wrong with the motivations and argumentations of individuals when the voting moment comes.

Waldron's main argument in defence of reasonable disagreement relates to the what he calls as the "circumstances of politics", an idea borrowed from Rawls' notion of the "circumstances of justice". The main difference between these two concepts is that the Rawlsian on concerns the fundamental aspects of justice as fairness (moderate scarcity and limited altruism), whilst Waldron's "circumstances of politics" pays attention to the disagreement generated by such principles.

Accordingly, Waldron's thesis of the "circumstances of politics" goes hand in hand with a radical defence of the majority rule as the most democratic way to make political decisions. Two reasons seem to make majority rule the most democratic tool. First, it respects and enhances difference of opinions about justice and the fundamental values. This means that it does not require to set aside or sacrifice our own beliefs in favor of a "fancied" consensus. Second, majority rule "embodies a principle of respect for each person in the processes by which we settle on a view to be adopted as ours even in the face of disagreement" (Waldron 1999: 109).

Majority-rule decision-making provides - as Waldron contends - the best argument in defence of the principles of justice, by being the fairest method for making political decisions when people disagree about them. The fact of the recurring alternation between majority and minority in the political and legislative arena 
allows majoritarian forces to be in a position to determine the political agenda and to propose a fair and open discourse about all those issues they consider as relevant at some point; furthermore, a majoritarian process allows minorities to influence decision-making processes and to highly contribute to the political discourse. Finally, Waldron emphasises that majoritarianism "will often ensure that no one party or faction monopolizes all the bases of current decision-making" (Waldron 1999: 188).

Elsewhere, Waldron has stressed that majoritarian decision-making is the best way to give individual's view the broadest and deepest attention and care, by admitting the necessity to assign to everyone an equal attention and care for their views. By upholding this thesis, Waldron emphasises how majoritarian democratic deliberation looks like the fairest method for decision-making; still, Waldron argues that that majoritarian system is "a natural interpretation of the physical aggregation of forces in the physics of consent" (Waldron 1999: 148).

Although it seems that Waldron accepts the Rawlsian thesis of reciprocity in giving an equal attention to every view on the political scene, it is to say that he fails in attributing to majoritarian decision-making process the "magic" power to resolve any kind of controversies. The idea that the majority always wins because it is "the majority" is simply misleading. Democracy is not a mere "celebration" of majoritarian strength over minorities; democracy is instead a debating process among different views and opinions and its aim is to lead towards a common decision and a shared consensus about the constitutional essentials, a decision which unifies majority and minorities instead of separating them.

\section{CONCLUSION}

As we have seen, within constitutional theories of democracy different approaches can be traced: down one path, liberal theorists à la Rawls believe that moral disagreement should be gradually overcome or reduced at least by accepting the burdens of judgement and applying the principle of neutrality when issues about fundamental values and the constitutional essentials are at stake. Down another path, defenders of the centrality of reasonable disagreement within deliberative and constitutional process reject 
the principle of neutrality and the idea of reducing or setting aside disagreement about fundamental moral values, by emphasising that it would mean to jeopardize the real essence of democracy.

The thesis I emphasise here is that we should distinguish between two different circumstances in which disagreement takes place: down one path, disagreements which arise on moral and ethical issues; down another path, disagreements may concern purely political issues as well as the constitutional essentials. My argument underlines that disagreement on individual moral and ethical issues is a natural, unquestionable and, in some sense, desirable condition of human being, since it affects to the most personal and experiential domain of individuals (likewise the Rawlsian "background culture").

Conversely, when dealing with purely political issues or when constitutional essentials are at stake, we should make a strong reciprocal effort to reduce our disagreement on fundamental common values and to achieve the widest possible consensus, in the vein of the Rawlsian overlapping consensus, which aims at reaching a deep, broad and stable consensus on the constitutional essentials. At the same time, such a consensus requires to resolve, as far as possible, our disagreement about how democracy works or should work and on what constitutional essentials mean for us.

I eventually suggest separating the two stages of our "discourse ethics: 1. Disagreements about the background culture, which oppose issues with not have relevance for our public political sphere, but that only concern the sphere of our personal and individual relationships; 2. Disagreements that, by contrast, arise when debating on the principles of justice and on the meaning of democratic citizenship. In this case, the principle of neutrality might help us to overcome disagreements on constitutional essentials, and to reach a compromise on what unites in a body politic us as free and equal citizens, rather than pursuing a divisive approach to democratic values. 


\section{LITERATURE}

Ackerman, B. (1991) We the People, Volume 1: Foundations. Cambridge (Mass.): Harvard University Press.

Archard, D. (2001) "Political Disagreement, Legitimacy and Civility", Philosophical Explorations: An International Journal for the Philosophy of Mind and Action, 4(3): 207-222.

Bellamy, R. (1996) "Pluralism, Liberal Constitutionalism and Democracy: A Critiques of John Rawls's (Meta)Political Liberalism". In: Meadowcroft, J. (ed.), The Liberal Political Tradition: Contemporary Reappraisals. Cheltenham: Edward Elgar, pp. 77-100.

Bellamy, R. (1999) Liberalism and Pluralism. Towards a Politics of Compromise. London \&New York: Routledge.

Bellamy, R. (2007) Political Constitutionalism. A Republican Defence of the Constitutionality of Democracy. Cambridge: Cambridge University Press.

Besson, S. (2005) The Morality of Conflict. Reasonable Disagreement and the Law. Oxford and Portland (OR): Hart Publishing.

Caney, S. (1998) “Liberal Legitimacy, Reasonable Disagreement and Justice", Critical Review of International Social and Political Philosophy, 1(3): 19-36.

Cohen, J. (2003) "For a Democratic Society". In: Freeman, S., (ed.), The Cambridge Companion to Rawls. Cambridge (Mass.): Cambridge University Press, pp. 86-138.

Estlund, D. (2000) "Jeremy Waldron on Law and Disagreement", Philosophical Studies, 99: 111-128.

Ferrara, A. (2008) The Force of the Example. Explorations in the Paradigm of Judgment. New York: Columbia University Press.

Ferrara, A. (2014) The Democratic Horizon. Hyperpluralism and the Renewal of Political Liberalism. Cambridge: Cambridge University Press.

Freeman, S. (2007) Rawls. London \&New York: Routledge. 
Larmore, C. (2003) "Public Reason”. In: Freeman, S. (ed.), The Cambridge Companion to Rawls. Cambridge (Mass.): Cambridge University Press, pp. 368-393.

Rawls, J. (1993) Political Liberalism. New York: Columbia University Press.

Reidy, D. (2006) "Reciprocity and Reasonable Disagreement: From Liberal to Democratic Legitimacy", Philosophical Studies, 132(2): 1-49.

Talisse, R. (2003) "Rawls on Pluralism and Stability", Critical Review, 15: 1-2.

Vinx, L. (2009) "Republicanism and Judicial Review: A Review of Richard Bellamy Political Constitutionalism. A Republican Defence of the Constitutionality of Democracy", University of Toronto Law Journal, 591-597.

Waldron, J. (1999a) Law and Disagreement. Oxford: Oxford University Press.

Waldron, J. (1999b) The Dignity of Legislation. Cambridge: Cambridge University Press. 
CIP - Каталогизација у публикацији

Народна библиотека Србије, Београд

$1: 32(082)(0.034 .2)$

$32: 81^{\prime} 42(082)(0.034 .2)$

DISKURS i politika [Elektronski izvor] = Discourse and Politics $/$ priredili, edited by Dejana M. Vukasović and Petar Matić. - Belgrade : Institute for Political Studies, 2019 (Žitište : Sitoprint). - 1 elektronski optički disk (CD-ROM) ; $12 \mathrm{~cm}$

Tiraž 100. - Napomene i bibliografske reference uz tekst. -

Bibliografija uz svaki rad. - Abstracts.

ISBN 978-86-7419-308-2

1. Up. stv. nasl.

а) Филозофија политике -- Зборници б) Дискурс анализа -- Политички аспект -- Зборници

COBISS.SR-ID 277718796 


\section{DISCOURSE AND POLITICS}

International Thematic Collection of Papers

ISBN 978-86-7419-308-2

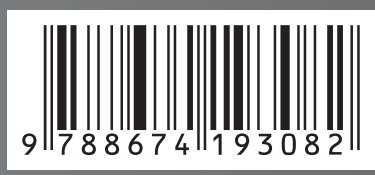

